University at Albany, State University of New York

Scholars Archive

Educational Theory and Practice Faculty

Scholarship

Educational Theory and Practice

$4-2010$

\title{
Technology-supported learning innovation in cultural contexts
}

Jianwei Zhang

University at Albany, State University of New York, jzhang1@albany.edu

Follow this and additional works at: https://scholarsarchive.library.albany.edu/etap_fac_scholar

Part of the Education Commons

\section{Recommended Citation}

Zhang, Jianwei, "Technology-supported learning innovation in cultural contexts" (2010). Educational Theory and Practice Faculty Scholarship. 9.

https://scholarsarchive.library.albany.edu/etap_fac_scholar/9

This Article is brought to you for free and open access by the Educational Theory and Practice at Scholars Archive. It has been accepted for inclusion in Educational Theory and Practice Faculty Scholarship by an authorized administrator of Scholars Archive. For more information, please contact scholarsarchive@albany.edu. 
Zhang, J. (in press). Technology-supported learning innovation in cultural contexts. ETR\&D

(Educational Technology Research and Development). (DOI: 10.1007/s11423-009-9137-6)

Running Head: INNOVATION IN CULTURAL CONTEXTS

Technology-Supported Learning Innovation in Cultural Contexts

\author{
Jianwei Zhang \\ Department of Educational Theory and Practice \\ University at Albany, SUNY \\ 1400 Washington Ave, ED 115B \\ Albany, NY 12222 USA \\ Phone: $1-518-442-4007$ \\ Fax: 1-518-442-5008 \\ Email: jzhang1@albany.edu
}




\title{
Technology-Supported Learning Innovation in Cultural Contexts
}

\begin{abstract}
Many reform initiatives adopt a reductionist, proceduralized approach to cultural change, assuming that deep changes can be realized by introducing new classroom activities, textbooks, and technological tools. This article elaborates a complex system perspective of learning culture: A learning culture as a complex system involves macro-level properties (e.g., epistemological beliefs, social values, power structures) and micro-level features (e.g., technology, classroom activities). Deep changes in macro-level properties cannot be reduced to any component. This complex system perspective is applied to examining technology-supported educational change in East Asia and analyzing how teachers sustain the knowledge building innovation in different contexts. Working with the macro-micro dynamics in a learning culture requires a principle-based approach to learning innovation that specifies macro-level changes using principle-based instead of procedure-based terms and engages teachers' deep reflection and creative engagement at both the macro- and the micro-level.
\end{abstract}

Keywords: Learning culture, Learning innovation, Technology, Emergentism, Complex system, Principle-based innovation 
Reforming education systems to address the knowledge society challenge is of global interests (UNESCO, 2005). Researchers from around the world have been exploring new learning programs - often supported by new technologies - to increase student capabilities of productive and collaborative knowledge work (e.g., Edelson, Gordin, \& Pea, 1999; Krajcik, Blumenfeld, Marx, Bass, \& Fredricks, 1998; Linn \& Slotta, 2000; Paavola, Lipponen, \& Hakkarainen, 2002; Scardamalia \& Bereiter, 2006; van Aalst \& Chan, 2007; van Joolingen \& de Jong, 2007). These learning innovations involve new learning activities (e.g., inquiry, group work), curriculum resources, and technology tools. Common to many of them is a deeper pursuit of cultural change (see also, Bielaczyc, 2006; Bielaczec \& Collins, 1999). The present article examines technologysupported learning innovation in specific cultural contexts. It begins with laying out two disturbing phenomena related to technology and learning research. A complex system perspective of learning culture is then presented to explain reasons behind the two phenomena and enlighten strategies to enable deep change in learning culture.

\section{Introduction: Two Disturbing Phenomena}

Using technology to promote deep innovation and cultural change in schools proves difficult. There are two phenomena that particularly disturb researchers. The first pertains to the adoption of technology in different cultures. There is growing interest in and strong argument for using new technologies as an agent of cultural change in education (e.g., Girod \& Cavanaugh, 2001; Price \& Oliver, 2007). However, educational practitioners in a culture often choose "domesticated technologies" (Salomon \& Almog, 1998) that do not affect life in classrooms much, and use them in culturally familiar ways (Zhang, 2007). Why is it so hard for new technologies to play out their transformative role? The second phenomenon is more at the classroom level and relates to the 
ritualization and "lethal mutation" of learning innovations in implementation (Brown \& Campione, 1996). When implemented in classrooms, many innovation programs (e.g., cooperative learning) tend to be degraded and ritualized as surface activities and procedures. These classroom activities and procedures are regarded as the means to enabling deep change in the learning culture. But oftentimes, there is no deep change evident after the advocated learning activities have been carried out.

The above two phenomena have been discussed separately in the literature. But they are actually connected and both associated with an essential issue in educational research: How should we conceptualize a learning culture and the nature of its change? This paper reflects on this issue and elaborates a complex system perspective on learning culture. This complex system approach is then applied to examining educational change at a regional and a classroom level. The analysis at the regional level focuses on technology-supported educational change in East Asia that has a distinctive learning culture. At the classroom level, analyses are provided to look at how teachers pursue deep change using the knowledge building pedagogy and technology (Scardamalia \& Bereiter, 2006) through a principle-based approach.

\section{Reflecting on the Reductionist Approach to Learning and Technology Research}

Learning and technology research has long been dominated by a reductionist thinking. In earlier research on technology in education, a large number of studies searched for media effects - whether one medium is better than another in enabling effective learning. A conclusion was that comparing the effects of different media is not a productive question for research, because media effects can never be separated from method effects-effects of instructional designs (Kozma, 1994). Intersecting with research on media effects are investigations of the role of technology in educational change. A critical look at the literature on this topic indicates that 
researchers ask a similar question as that of media effects, but focusing on technology's impact on the practices of teachers and schools: Can new technology cause changes towards innovative, constructivist pedagogical practice or classroom culture? There are studies on both sides showing that using new technologies causes constructivist practices (e.g., Becker \& Ravitz, 1999) or technology does not affect teaching practice (e.g., Cuban, Kirkpatrick, \& Peck, 2001). A middleway stance on this issue suggests that technology can be a catalyst of pedagogical change, but does not cause change by itself (e.g., Lin \& Hatano, 2003; Salamon \& Perkins, 1996). The influence of technology is mediated by teachers' interconnected beliefs about learners, teaching, and the role of technology within a school context (Windschitl \& Sahl, 2002).

Despite of the variations in research focus and contexts, the above two lines of research on technology impact share the same thinking framework in problem formulation and underlying beliefs about causality, which are characteristic of a reductionist, analytic approach. This approach assumes that complex phenomena can be explained completely in terms of other, more fundamental factors. Learning culture and teaching practices taking place in it are conceived as a resultant entity, on which new technology and learning activities are created to have an impact. Deep learning goals and target learning cultures are reduced to a list of things to do and to use: component tasks, activities, procedures, resources, tools, and so forth. Common to traditional and many modern models of teaching (e.g., WebQuests, many forms of project work), tasks and activities - instead of big ideas — become the center of learning design and classroom practice (Scardamalia \& Bereiter, 1991). Thus we are puzzled when no deep change takes place after the things on the "to do list" have been done; and when new technologies, which are conceived as an agent of change, fail to cause change in the traditional learning culture and are instead domesticated by it. Researchers and reformers are often blamed that the new learning models they 
have developed are not specific enough (cf. Black \& William, 1998). Teachers and schools are blamed that they have not implemented the new learning models with high fidelity (Boddily, 1998). Beyond the above reasons, we need to examine the fundamental framework that has been used to understand learning culture and its change. Put it briefly, we should appreciate that a learning culture as a complex system is more than the sum of its components (e.g., activities, tools).

\section{Toward a Complex System Perspective of Learning Culture}

A complex system is a system composed of interacting parts that as a whole exhibit one or more properties not assumed by any of the individual parts. Complex systems pervade nature and human society. Examples include ant colonies, climate, brains, stock markets, and many more. These complex systems are characterized by multilevel organization, multiple interactions between many heterogeneous components, and dynamic, often invisible processes that constantly evolve and unfold over time (Arthur, 1999; Hmelo-Silver \& Azevedo, 2006). An important concept in the complex systems literature is emergence, which refers to the way system-level properties arise out of multiple, relatively simple interactions among the component parts (O'Connor, 1994). For example, human consciousness is an emergent property grounded in and arising from interactions among brain cells. It is a system-level quality that is not assumed by any of the cells, thus cannot be reduced to biological and chemical processes.

Research on complex systems has led to refreshed interest in and deeper inquiries of emergentism, a school of philosophical thinking started by several British philosophers (e.g., Morgan, 1923). Emergentism has important implications to research of human social practices such as education. A social organization or practice is a dynamic complex system that has many component parts as well as system-level properties. There are dynamic interactions between 
micro-level components and macro-level properties, which can be conceptualized as two types of causations. Supervenient causations refer to the bottom-up emergence of more complex, "higher level" properties from the organization and interaction of simpler, "lower level" component parts. Downward causations represent the significant influence of the overall system organization on the function of any component (Kim, 2006; Sawyer, 2003).

The complex system perspective, emergentism in particular, provides a productive framework for studying learning culture and its change. Although the term of "learning culture" or "classroom culture," "pedagogical culture" - has been widely and increasingly used in publications, it has rarely been explicitly defined. In this article, when the term of "learning culture" is used, it refers to historically-rooted cultural attributes related to learning and education carried by an identifiable community (e.g., a nation, a regional community, a school). These cultural attributes are demonstrated as collective, intuitive understanding of what learning is about and how it should be approached in practice, as well languages, signs, and social norms that mediate learning and teaching. A wide range of phrases have been used in the literature to characterize learning cultures: beliefs about knowledge and learning, learning orientations, power structures in classroom, social organization of learning, valued learning outcomes, knowledge content, learning strategies and activities, technology integration, time and spatial configurations, and so on (e.g., Bielaczyc, 2006; Little, 1990; Tweed \& Lehman, 2002). Conceptualizing learning culture as a complex, social practice system helps us to understand the relationships among the above items, and further enlightens the differentiation between macro-level properties of a learning culture and specific, micro-level characteristics associated with particular components. The evolution of a learning culture is the emergent result of the interactions between its macrolevel properties and micro-level components - the macro-micro dynamics (see Figure 1). 
Insert Figure 1 about here

Macro-level properties characterize a learning culture as a whole. They are not as tangible as classroom activities, procedures, resources, and technologies tools; but are essential across different contexts and facets of educational practice in a community. Core properties at the macrolevel include:

(a) Epistemologies-in-practice. These refer to epistemological beliefs about knowledge, learning, and teaching deeply held and intuitively enacted by an educational community. One of the core dimensions is the continuum from an objectivist to a constructivist epistemology. Recent reform programs are dedicated to transforming classroom practices in line with a constructivist epistemology, with students engaging in active meaning-making, critical thinking, and creative knowledge construction in socially situated contexts of learning (Bransford, Brown, \& Cocking, 1999). Students as knowledge builders are not to find the single true answer, but to generate and work on promising ideas (e.g., theories, explanations, models, work plans) and continually improve them in terms of clarity, coherence, explanatory power, and usefulness (Bereiter, 2002).

(b) Social values applied to learning and education: These relate to the questions of what characterizes the "educated person" in a particular culture (Levinson, Foley, \& Holland, 1996) and what kinds of intrinsic learning outcomes and associated extrinsic benefits are highly valued by a society or community. For example, is creativity more important than obeying social rules? Are individual achievements more rewarded than contributing to the collective good? Are external 
incentives (e.g., moving to a higher social status) more important than intrinsic incentives (i.e., learning for the sake of learning)?

(c) Power structures in educational practice: In cultural studies, a key factor related to power structures is power distance, which refers to the extent to which members of a society accept that power in institutions and organizations is distributed unequally. People in large power distance societies accept a hierarchical order in which everybody has a place that does not need further justification. "People in small power distance societies strive for power equalization and demand justification for power inequalities." (Hofstede, 1983, p. 83). A core relationship in educational practice is the relationship between the teacher and students. Recent innovation programs pursue a shift from a teacher-centered, authoritative classroom structure toward a democratic structure of participation (Bielaczyc \& Collins, 1999).

A contemporary learning culture involves a number of major components: curriculum guidelines; learning tasks, activities and procedures; learning resources and technologies; assessments of learning; and institutional organization of schooling. Micro-level properties associated with these component parts of a learning culture reflect as choices and decisions regarding specific issues such as: What kinds of knowledge content is taught and how is it organized and sequenced? What kinds of learning strategies and activities are conducted? What technologies are used? How is the classroom spatially organized? Recent education reforms have been primarily working on changes in the components, expecting that deep change in classroom culture can be enabled by introducing new curriculum standards and textbooks, learning tasks and activities, and technologies. Even though some reform programs recognize the importance of inducing new teaching beliefs in schools, there is a lack of effective strategies to address belief change, which cannot be packaged and handed over to teachers. 
According to emergentism, macro-level properties are as real as micro-level components, and these two levels interact with each other in a significant manner. The effects of microcomponents (e.g. technology use, classroom activities) on the high-level properties of a learning culture should be understood as supervenient causations. Such causations are analogical to chemical effects instead of mechanical effects. It is the interactions of multiple component entities that give rise to new macro-level properties of a culture, the evolution of which cannot be fully predicted and may not be attributed to any one of the components in a reductionist way.

On the other hand, the macro-level properties of a learning culture also have significant downward causal influences on its components. A learning culture, as a whole, shapes the needs for technologies as well as the way educators understand and use technologies. This leads to the fact that educators often choose "domesticated technologies" that is consistent with their exiting culture, hence do not affect life in the classroom much (Salomon \& Almog, 1998). Similarly, when incorporating new classroom processes and activities, teachers tend to reinterpret the processes and activities in light of their beliefs and conceptions about learning and teaching and adjust the processes and activities accordingly. By assimilating domesticated technologies and culturally compliant teaching activities, an existing teacher-centered classroom culture can be maintained, avoiding deep conflicts with the incorporated technologies (e.g., computers) and activities (e.g., cooperative learning).

The above complex system perspective, macro-micro dynamics in particular, provides an explanatory framework for understanding the two disturbing phenomena identified in the beginning: The difficulty of using technology as an agent of cultural change and the risk of lethal mutation and ritualization of learning innovations in implementation. The widely observed phenomena of using new technologies, activities, and resources to support a traditional learning 
culture without deep change can be further explained using an important concept in the emergentism literature: "multiple realizability" of a complex system. This concept indicates that a macro-level property can be realized through multiple mechanisms at the component level (Fodor, 1974; Sawyer, 2003). A teacher-centered authoritative power structure can be maintained whether it is in a chalk-and-board or an online and multimedia environment, whether students are attending lectures or doing hands-on project work, whether they are learning individually or in small groups.

To further elaborate the complex system perspective, I will use this framework to analyze two examples. Regarding the difficulty of using technology as an agent of cultural change at a regional level, I will discuss the use of technology in the cultural contexts of East Asia. Focusing on strategies to avoid lethal mutation and ritualization of learning innovations in classrooms, I will discuss the implementation of the knowledge building pedagogy and technology (Scardamalia \& Bereiter, 2006) in both Western and Eastern cultural contexts.

\section{How Eastern Learning Culture Shapes Technology Use}

Eastern culture is rooted in the tradition of Confucianism; Western culture is rooted in that of Socratic philosophy. When we compare learning practices in these two cultures, it is important to keep in mind that the West versus East distinction is more of a continuum than a dichotomy; and that there are wide variations within each society.

Macro-Properties of Eastern Learning Culture

In terms of epistemological beliefs, Easterners hold a more authoritative view of knowledge and learning, assuming that intellectual elites create knowledge and define moral principles, which are interpreted and communicated to the public by scholars, and to students by teachers. Crosscultural comparisons revealed important differences in beliefs about learning (see Tweed \& Lehman, 2002). Compared to their Western counterparts, Chinese students and instructors are 
more likely to treat texts and the instructor as highly authoritative sources of knowledge, expecting the instructor to provide more structure and guidance. Learners prefer to first understand knowledge from these sources and postpone their questioning and commenting. Western students and educators tend to attach greater importance early in the learning process to questioning and criticizing information presented by an instructor (Pratt \& Wong, 1999). Eastern students focusing on knowledge acquisition should not be simply interpreted as passive rote learning. Instead, they value active, effortful, and reflective learning. Deep engagement and reflection are conceived as core qualities of a good student (Gerbic, 2006; Jin \& Cortazzi, 1998; Stevenson and Stigler, 1992; Tweed \& Lehman, 2002). Qualified teachers often model effortful and reflective learning behaviors, stimulate learners' thinking and reflection by asking thought-provoking questions, and design and use informative assignments to promote flexible understanding of knowledge (Lee, Liu, \& Lee, 2003; Stevenson \& Stigler, 1992).

In terms of social values, Easterners value collective good over individual interest. They seek harmony, order and well-being in a society by emphasizing social obligations of individuals and social classes, who should behave in line with the social expectations of their social roles (Huang, 2002). In education, this collectivist thinking gives more weight to social norms (Li, 1996), and urges students to acquire socially recognized essential knowledge and moral principles, and transform their own thinking and behaviors accordingly (Tweed \& Lehman, 2002; Zhang, 2007). In a study, Jin and Cortazzi (1998) compared the responses of Chinese and British students on a variety of attitudinal items. When asked what constitutes good teaching, Chinese students were more likely than British students to define a good teacher as someone with deep knowledge who sets a good example and teaches students about life. British students were significantly more likely to define a good teacher as someone who is helpful, sympathetic to individual students, and who 
arouses their interest and organizes a variety of classroom activities. The collectivist culture is also associated with a pragmatic orientation to learning. Eastern learners are more likely to see education as a means to achieving practical goals, for example, to pass competitive exams, to gain social recognition, to secure a job of civic service, or to pursue a higher social status (Tweed \& Lehman, 2002).

In terms of power structures, members of Eastern societies generally accept larger power distance (Bond \& Hwang, 1990). Individuals of all social classes are urged to fulfill the requirements of their social roles. In education, greater emphasis is placed on strictness and discipline, and less emphasis on children's independence and creativity (Ho \& Kang, 1984). Students should show full respect to their teachers, who are considered authoritative professionals. Several studies reported that Chinese students were more respectful of their teachers than British and Australian students (Aldridge \& Fraser, 2000; Jin \& Cortazzi, 1998). The social organization of schooling in Eastern culture tends to be more centralized, with the central government designing and executing policies and standards for school finance, curriculum, textbooks, assessment, and teacher preparation. A current direction in educational reforms is to decentralize the educational systems and turn over more control to local authorities and schools.

\section{The Challenge of Learning Innovation in Eastern Societies}

As noted above, Eastern culture has a more authoritative view towards knowledge and learning, a more teacher-dominated classroom structure, and a stronger focus on essential knowledge and moral principles, valuing obeying social norms. Facing the challenge of a knowledge society, the East Asian nations are embarking on initiatives to evolve a more democratic and creative learning culture. They look upon information technologies as a revolutionary tool to help achieve this goal (Hung \& Chen, 2003; Mizukoshi, Kim \& Lee, 2000; 
Ziguras, 2001). For example, China launched the "Connecting-Every-School" project in 2000 as a part of its Quality Education initiative. The development of new technologies is integrated with its efforts of national curriculum reform. Although computers and the Internet are increasingly used in schools, the expected transformative impacts of new technologies on educational change are far from becoming evident. The new technologies are mostly assimilated into existing classroom structures to support teacher-dominated, group-based knowledge acquisition (Zhang, 2007).

Eastern epistemological beliefs, social values, and power structures in education have a deep impact on educators' needs and choices of learning software and hardware, as well as teaching methods associated with these tools. As a result, teachers prefer content-bound and curriculumcompliant courseware and resources, including tutorials, drills-and-practices, computer-assisted tests, and Web-based gateways that sort learning resources in line with the national curriculum (Zhang, 2002, 2007). In contrast, in Western learning culture that is overall more learner-centered, activity-focused, and individualized, technology is more likely to be used as content-open productivity tools (e.g. word processing, simulations, explorative environments, graphics, spreadsheet, database, presentation) (Becker, Ravitz, \& Wong, 1999). In East Asian schools, there is also a strong need of digital projectors or LCD display boards. An international study showed that Hong Kong had a much higher ratio of schools with digital projectors or LCD display boards than many Western countries (Law, Yuen, Ki, Li, \& Lee, 1999). These software and hardware resources that are of Eastern teachers' preferences can help them to deliver demonstrations and lectures in large classes without significant changes in the teacher's role. Even though exploratory learning tools are sometimes adopted, they are often used to aid teachers' demonstration and lecturing. An example is the Geometry SketchPad, a discovery-oriented tool for geometry learning designed in the US. This software has been widely adopted by teachers in China, but mostly as a 
teaching tool to help create vivid demonstrations (see examples in Chinese at http://www.gspinchina.com).

Another example of the downward causations of Eastern culture on technology use is the adaptation of distance learning in higher education (Zhang, 2007). Distance learning was invented in UK and the US as a bond of learning approach and technology rooted in the conception of selfpaced and open learning. Since it was imported to East Asia, distance learning has been adapted in many aspects. Unlike the individualized, self-paced learning adopted by institutions in UK and other Western nations, distance learning in China has been localized as group-based distance lecturing (see also, Tu \& Twu, 2002; Zhu, Gu, \& Wang, 2003), which organizes learners into classes to attend lectures at local learning centers. These lectures are delivered through television, VCDs/DVDs, satellite-based digital video broadcasting, videoconferencing systems, or Internetbased video/audio streams synchronized with PowerPoint slides. Contrary to the expectation that Chinese instructors may not be able to lecture and dominate learning any more in a Web-based environment (Lee, 2004), they naturally extend group-based lecturing into the virtual world. Interestingly, Eastern learners also favor this approach. In a survey among distance learners in undergraduate and graduate programs, a majority of learners stressed the importance of studying together with their classmates in a classroom and interacting intensively with the instructor (Zhang, $\mathrm{Wu}, \& \mathrm{Li}, 2003)$. This result is consistent with observations of students in Korea (Jung, 2000) and South East Asia (e.g., Malaysia) (Ziguras, 2001). It is almost impossible to identify who first made the above adaptations and reinventions in the Asian context; they seemed to have emerged from a collective process in which designers, instructors, students, and policy-makers all played important parts. 
As the above analyses suggest, the epistemological beliefs, social values, and power structures central to Eastern learning culture shape the emergent needs, selection, understanding, design, and use of technology. This downward influence is realized through educators' efforts to build deep connections between new technologies and ongoing educational practices in their local contexts, fostering the historical descending of their learning culture. A new technology only has its meaning potentials; its meaning needs to be actualized and contextualized by members of a community. By adapting technology to their local contexts, teachers connect technology to their pedagogical beliefs, social values, and activity patterns, and eventually achieve a dynamic fit with the contexts. This process contributes to the continuity of a learning culture, but also cultural resistance to deep change. Learning technology is so deeply embedded in cultural contexts, thus cannot be imported from one culture to another in a simplistic way.

\section{Working with the Macro-Micro Dynamics for Principle-Based Innovation}

A complex system perspective suggests the importance of working with the macro-micro dynamics in pursuing deep and sustainable educational change. Teachers implementing an innovation program need to work with both macro-level properties and component features of their learning culture and engage in deep reflection across these two levels. Enabling teachers' creative and deep engagement of this nature requires a shift in the design of new learning programs from a proceduralized, script-like approach to a principle-based approach.

As noted earlier, rooted in a reductionist framework, many new learning programs developed by educational agencies and researchers adopt a procedurealized approach. Deep learning goals and target learning cultures are reduced to a list of things to do and to use (see also, Hong \& Sullivan, in press), in accordance with a highly-structured, prescriptive framework of instructional design that focuses on clearly defining and sequencing component tasks (Gagne, Wager, Golas, \& 
Keller, 2005). Clearly spelling out the procedures, activities, and tools in an innovation program can help ease teachers' adoption. However, reducing deep cultural change to a list of things to do and to use runs against the complex nature of learning culture as a dynamic social system, often leading to ritualized surface classroom activities instead of deep change.

A principle-based approach to learning innovation defines a set of core educational values and principles to inform decision-making of teachers, who appropriate these principles, make reflective interpretation and discretionary judgment, and develop specific designs and actions to achieve desired outcomes (Zhang et al. 2008). Core properties characterizing a new learning culture are primarily represented as new epistemological beliefs, social values, and power relationships underpinning educational practice. These macro-level properties can be better specified through learning principles instead of activities, procedures, and technology tools. Therefore, deep learning innovations need to seize on the "thinking function" of learning principles (Brown \& Campione, 1996) to engage teachers in re-understanding core issues of learning and teaching (e.g., nature of knowledge and knowledge creation, how students learn and think), creating new meanings for themselves, create and improvise classroom designs, and critically reflecting on their classroom practice in light of the new understanding (Hargreaves, 1999). Their role is not to simply implement an "external" innovation or reform, but to develop ownership over the innovation and capacity to deepen the underpinning principles themselves (Coburn, 2003). This principle-based approach to learning innovation represents an idea-centered - as opposed to task- and activity-centered-framework of teaching, with tasks and activities evolved in the service of student idea development (Scardamalia \& Bereiter, 1991). It further requires a flexibly adaptive, open-ended instructional design in which "initial designers," teachers, and students can all contribute to the unfolding classroom processes (Schwartz et al. 1999; see 
also Hannafin et al. 1999; Sawyer 2004). Students are actively engaged in understanding and developing knowledge goals and deciding on what they need to do to achieve their goals (Zhang, Scardamalia, Lamon, Messina, \& Reeve, 2007). They engage in deep work with ideas and work with their teacher to choose and evolve various activity structures, procedures, and tools in support of idea development, instead of the following through pre-specified, ritualized activity procedures (e.g., seatwork, presentation) in daily school life.

To what extent a principle-based approach to innovation can succeed in schools? How? To answer these questions, this section looks at the implementation of the knowledge building pedagogy and technology (Scardamalia \& Bereiter, 2006) as an example of principle-based innovation. The goal of the knowledge building pedagogy is to prepare students for a knowledgebased society in which knowledge creation pervades. In a knowledge building community, students contribute their ideas as public, conceptual artifacts, which are continually revisited, critically examined, applied, revised, re-organized, and risen above towards higher levels of conceptualizations and deeper understandings (Scardamalia \& Bereiter, 2006). Knowledge building in classroom is guided by a set of 12 principles (Scardamalia, 2002). Several principles address issues related to epistemological beliefs, social values, and power structures underpinning educational practices. For example, the principle of improvable ideas indicates that all ideas should be treated as ever improvable. Students work continuously to improve the quality, coherence, and utility of ideas, instead of finding out a single true answer. For idea improvement to prosper, the classroom culture must encourage participants to take risks - revealing ignorance, voicing half-baked notions, giving and receiving criticism. Collective responsibility for community knowledge points to the importance of contributing to the collective knowledge enterprise of the community, with students working as a team to continually improve their ideas, not simply to 
advance their own. Epistemic agency highlights the need to turn over high-level control of knowledge work to students, dealing with problems of goals, motivation, evaluation, and longrange planning - problems that are normally left to teachers. There are several principles at a more specific level, informing but not specifying classroom activities. These include: authentic problems and real ideas, knowledge building discourse, constructive uses of authoritative sources, embedded and transformative assessment, etc. The knowledge building process is further supported by Knowledge Forum ${ }^{\circledR}$, a computer-based collaborative knowledge-building environment (Scardamalia, 2004). Knowledge Forum provides a communal space where students can share their understanding and work together to continually improve the ideas represented there. Implementing a principle-based innovation, such as knowledge building, poses great demands on teachers. A part of my recent research in collaboration with my colleagues has been focusing on identifying strategies for enabling and sustaining knowledge building as a principled innovation (Zhang, Hong, Teo, Scardamalia, Morley, 2008; Zhang \& Scardamalia, 2007). Additionally, I had the opportunity to coordinate the Analyses, Reflections, and Tours event at the annual Knowledge Building/Knowledge Forum Summer Institute (http://ikit.org/summerinstitutes.html) from 2005 to 2007, which was aimed at creating partnerships between teachers and researchers internationally. A team of teachers from Canada, Finland, Hong Kong, and Spain has participated in this event to share and elaborate their designs of knowledge building; researchers looked into their knowledge building processes and provided feedback using a set of analytic tools. The above research and practice helped to reveal significant efforts of the teachers to enable and sustain knowledge building in different school and cultural contexts. Several of the key processes are elaborated below, focusing on how the teachers work with the macro-micro dynamics. 
(a) Principle-based understanding and design. The knowledge building teachers continually think about macro-level, core issues related to their classroom culture (e.g., epistemologies, social values, and power relations) in light of the knowledge building principles, as they develop and implement specific classroom designs. For example, related to the principle of epistemic agency, the teachers continually deepen their understanding of what this principle really means in relation to their current practice and what level of agency can be enabled among a particular group of children. They constantly develop, test and improve strategies to turn over more control to students in classrooms and online in Knowledge Forum, such as using a flexible collaboration structure that encourages students to group and re-group in the service of their inquiry needs and engaging students in co-designing and co-evolving classroom activities (Zhang, Scardamalia, Reeve, \& Messina, 2009). Through reflective observations of students' knowledge building, the teachers are often impressed by the level of thinking and work students are capable of. As a Kindergarten teacher commented: “My soul gets constantly amazed by what these young children can accomplish..." These observations further increase their trust in student agency and help them to envision new possibilities of having students take on more control over their knowledge building.

(b) Principle-based reflection on classroom processes. The teachers constantly reflect on classroom processes in light of the knowledge building principles: Are there idea improvements evident in student conversations? Are students enacting collective responsibility for community knowledge advancement? How can a teacher intervene in the knowledge building process without compromising students' epistemic agency? Critical reflections of the above kind are especially important when unfavorable events occur in the classroom. Through their reflection, teachers can figure out reasons behind the problems and work out a plan to move the community onto a 
productive route. For example, a Grade 5/6 teacher in Toronto once found that some of the students showed resistance to using Knowledge Form. Through his observation and reflection, he realized that the students had been asked to use Knowledge Forum too much for things that were not necessary, for example, to write down factual information instead of important ideas. He reflected in an interview: "So we have to really be careful of how we use the technology that is not for the sake of technology. It has to be for the sake of knowledge building. Some knowledge building happens in [classroom] talks, some happens in notebooks, and some happens there [in Knowledge Forum]."

(c) Identifying and overcoming barriers to enacting the principles in specific contexts. Enacting the knowledge building principles faces different practical conditions and barriers in different classroom settings and cultural contexts. Teachers need to understand the contexts, identify challenges and barriers, and develop effective strategies accordingly. They "need to be able to manage situations in which new knowledge about what to do must be created on the spot." (Lampert, 1999, p.168) As noted earlier, students in Eastern culture often expect the teacher to provide more guidance and structure, and give more weight to external, social value of learning (Tweed \& Lehman, 2002). Many teachers in Hong Kong found it challenging to engage their students in open-ended knowledge building discourse and critical thinking of ideas. To deal with this challenge, several teachers experimented with culturally adaptive strategies. For example, based on student engagement in online and face-to-face discussions, the teachers gave each student a participation score as a part of the final grading. They also set various awards to encourage question asking, idea improvement, critical comments, and so forth.

Through the above efforts, the teachers deepen their understanding of the core principles; develop, reflect on, and improve classroom designs; and address emergent problems in specific 
contexts. The knowledge building principles become as real as classroom activities, procedures, and tools, and are used as “thinking devices" (Wetsch 1998) to inform teachers' pedagogical thinking, decision-making, and reflection on action. The teachers transcend boundaries between core principles and specific activity designs and tool applications to identify possibilities and strategies to enable productive knowledge building, making knowledge building an everimproving practice. These efforts are substantially augmented through interactions among the teacher communities that engage in critical professional discourse, co-develop a shared repertoire of design strategies and classroom examples, and seek continual and collaborative improvement (Zhang et al., 2008). Working with both macro-level properties and component features in a learning culture and building a dynamic flow between them are critical to sustaining deep classroom change.

\section{Conclusions}

This article elaborates a complex system perspective of learning culture and its change. A learning culture is a complex system of social practice. It involves macro-level properties (e.g., epistemological beliefs, social values, power structures) and micro-level features (e.g., curriculum and textbooks, technology, classroom activities, assessment). The macro-level properties of an existing culture have significant downward causations to the component features, leading to the historical descending of the core cultural properties. The downward causations explain why new technologies are often assimilated into ongoing practice without causing deep change; and why new classroom activities and materials provided by reformers are often ritualized as surface procedures in implementation.

Many technology-based learning initiatives adopt a reductionist, proceduralized approach to cultural change, assuming that deep changes can be naturally realized by introducing new 
technological tools, curriculum and textbooks, classroom activities, and assessment. Current best practice of technology integration underlines that teachers should not only be provided with a set of new technological tools but also instructional designs and procedures specifying how the technological tools will be used. The complex system perspective further enlightens a principlebased approach to classroom innovation that specifies macro-level changes using principle-based instead of procedure-based terms. Teachers need to appropriate and deepen the underlying principles, evolve new designs in their contexts with their students, and engage in deep reflections across the macro- and the micro-level. In this sense, they are not merely users or implementers of external innovations, but themselves grassroots innovators. Enabling principled deep innovation in learning represent a challenge for both Eastern and Western societies, although the specific cultural contexts and barriers vary. The complex system perspective provides a framework to characterize a learning cultural context, define desired change, identify challenges and conflicts, and formulate new synergy across the macro and micro levels through collaborative efforts of innovation developers, administrators, teachers, and students.

\section{References}

Aldridge, J. M., \& Fraser, B.J. (2000). A cross-cultural study of classroom learning environments in Australia and Taiwan. Learning Environments Research, $\underline{3}, 101-134$.

Arthur, W.B. (1999). Complexity and the economy. Science, 284, 107-109.

Becker, H., \& Ravitz, J. (1999). The influence of computer and Internet use on teachers' pedagogical practices and perceptions. Journal of Research on Computing in Education, $\underline{31(4),}$ 356-385.

Becker, H. J., Ravitz, J. L., \& Wong, Y. (1999). Teaching, learning, and computing national survey report \#3: Teacher and teacher-directed student use of computers and software. Center 
for Research on Information Technology and Organizations, University of California, Irvine and University of Minnesota.

Bereiter, C. (2002). Education and mind in the knowledge age. Mahwah, NJ: Erlbaum.

Bielaczyc, K. (2006). Designing social infrastructure: Critical issues in creating learning environments with technology. Journal of the Learning Sciences, 15(3), 301-329.

Bielaczyc, K., \& Collins, A. (1999). Learning communities in classrooms: A reconceptualization of educational practice. In C. M. Reigeluth (Eds.), Instructional-design theories and models: A new paradigm of instructional theory (pp. 269-292). Mahwah NJ: Lawrence Erlbaum Associates.

Black, P., \& William D. (1998). Inside the black box: Raising standards through classroom

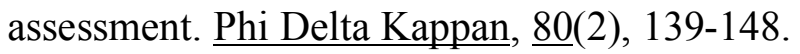

Bodilly, S.J. (1998). Lessons from New American Schools' scale-up phase. Santa Monica, CA: Rand.

Bond, M.H., \& Hwang, K.K. (1990). The social psychology of the Chinese people. In M.H. Bond (Eds.), The psychology of the Chinese people (pp. 213-266). Hong Kong: Oxford University Press.

Bransford, J. D., Brown, A. L., \& Cocking, R.R. (1999). How people learn: Brain, mind, experience, and school. Washington, DC: National Academy Press.

Brown, A. L., \& Campione, J. (1996). Psychological theory and the design of innovative learning environments: On procedures, principles, and systems. In L. Schauble \& R. Glaser (Eds.), Innovations in learning: New environments for education (pp. 289-325). Mahwah, NJ: Erlbaum. 
Coburn, C.E. (2003). Rethinking scale: Moving beyond numbers to deep and lasting change. Educational Researcher, 32(6), 3-12.

Cuban, L., Kirkpatrick, H., \& Peck, C. (2001). High access and low use of technologies in high school classrooms. American Educational Research Journal, 38(4), 813-834.

Edelson, D.C., Gordin, D.N., \& Pea, R.D. (1999). Addressing the challenges of inquiry-based learning through technology and curriculum design. Journal of the Learning Sciences, $\underline{8}, 391$ 450.

Fodor, J.A. (1974). Special sciences (Or: The disunity of science as a working hypothesis). Synthese, $\underline{28}, 97-115$.

Gagne, R.M., Wager, W.W., Golas, K.C., \& Keller, J.M. (2005). Principles of instructional design ( $5^{\text {th }}$ ed.). Belmont, CA: Wadsworth/Thomson Learning.

Gerbic, P. (2006). Chinese learners and online discussions. New opportunities for multicultural classrooms. Research and Practice in Technology Enhanced Learning, 1(3) 221-237.

Girod, M., \& Cavanaugh, S. (2001). Technology as an agent of change in teacher practice. T.H.E. Journal, 28 (9), 40,42,44,46-47.

Hannafin, M. J., Land, S., \& Oliver, K.M. (1999). Open learning environments: Foundations, methods, and models Vol. II. In C. Reigeluth (Ed.), Instructional design theories and models (pp.115-140). Mahwah, NJ: Lawrence Erlbaum Associates.

Hargreaves, D. H. (1999). The knowledge-creating school. British Journal of Educational Studies, $\underline{47}(2), 122-144$.

Hmelo-Silver, C. E., \& Azevedo, R. A. (2006). Understanding complex systems: Some core challenges. Journal of the Learning Sciences, 15, 53-61. 
Ho, D.Y.F., \& Kang, T.K. (1984). Intergenerational comparisons of child-rearing attitudes and practices in Hong Kong. Developmental Psychology, 20, 1004-1016.

Hofstede, G. (1983). Dimensions of national cultures in fifty countries and three regions. In J.B. Deregowski, S. Dziurawiec, \& R.C. Annis (Eds.), Expiscations in cross-cultural psychology (pp. 335-355). Lisse, The Netherlands: Swets \& Zeitlinger.

Hong, H. -Y., \& Sullivan, F. S. (2009). An idea-centered, principle-based design approach to support learning as knowledge creation. Educational Technology Research and Development, $\underline{57}, 613-627$.

Huang, X. (2002). What is "Chinese" about Chinese civilization? In: M. Mozaffari (Eds.), Globalization and civilizations (pp. 218-241). London: Routledge.

Hung, D., \& Chen, D.T. (2003). Online learning and information technology in the Asia-Pacific region. Educational Technology, $\underline{43}(3), 5-9$.

Jin, L. \& Cortazzi, M. (1998). Dimensions of dialogue: large classes in China. International Journal of Educational Research, $29,739-761$.

Jung, I. (2000). Technology innovations and the development of distance education: Korean experience. Open Learning, 15(3), 217-231.

Kim, J. (2006). Emergence: Core ideas and issues. Synthese, 151, 547-559.

Kozma, R.L. (1994). Will media influence learning? Reframing the debate. Educational

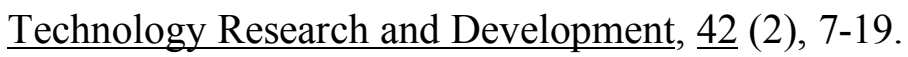

Krajcik, J., Blumenfeld, P. C., Marx, R. W., Bass, K. M., \& Fredricks, J. (1998). Inquiry in project-based science classrooms. Journal of the Learning Sciences, 7(3/4), 313-350.

Lampert, M. (1999). Knowing teaching from the inside out: Implications of inquiry in practice for teacher education. In G. Griffen (Eds.), The education of teachers: 98th Yearbook of the 
National Society for the Study of Education, Part 1 (pp. 167-184). Chicago, IL: University of Chicago Press.

Law, N., Yuen, H. K., Ki, W. W., Li, S. C., \& Lee, Y. (1999). Second international information technology in education study: Hong Kong SAR report, retrieved April 21, 2008 from http://sites.cite.hku.hk/full_report.htm.

Lee, D. (2004). Web-based instruction in China. Educational Technology Research \& Development, $\underline{52}(1), 101-105$.

Levinson, B., \& Foley, D., \& Holland, D. (Eds.), (1996). The cultural production of the educated person: Critical ethnographies of schooling and local practice. Albany: SUNY Press.

Li, X.-M. (1996). Good writing in cross-cultural context. Albany, NY: SUNY press.

Lin, X., \& Hatano, G. (2003). Technology, culture, and adaptive minds. Mind, Cultures, and Activity, $\underline{10}(1), 3-8$.

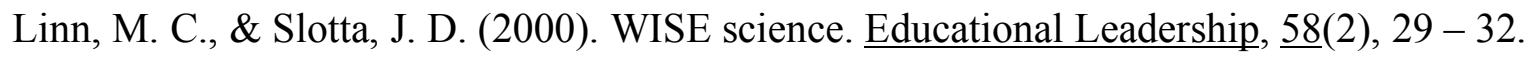

Little, A. (1990). Understanding culture: A pre-condition for effective learning. Paris: UNESCO.

Mizukoshi, T., Kim, Y., \& Lee, J. Y. (2000). Instructional Technology in Asia. Educational Technology Research and Development, $\underline{48(1), 101-112 .}$

Morgan, C.L. (1923). Emergent evolution. London: Williams and Norgate.

O’Connor, T. (1994). Emergent properties. American Philosophical Quarterly, 31, 91-104.

Paavola, S., Lipponen, L., \& Hakkarainen, K. (2002). Epistemological foundations for CSCL: A comparison of three models of innovative knowledge communities. In G. Stahl (Ed.), Computer Support for Collaborative Learning: Foundations for a CSCL community. Proceedings of the Computer-supported Collaborative Learning 2002 Conference (pp. 24-32). Hillsdale, NJ: Erlbaum. 
Pratt, D. D., \& Wong, K. M. (1999). Chinese conceptions of "effective teaching” in Hong Kong: Towards culturally sensitive evaluation of teaching. International Journal of Lifelong $\underline{\text { Education, }} \underline{18}, 241-258$.

Price, S., \& Oliver, M. (2007). Technology and change in educational practice (guest editorial). Educational Technology \& Society, 10 (1), 14-15.

Salomon, G., \& Almog, T. (1998). Educational psychology and technology: A matter of reciprocal relations. Teachers College Record, $100(2), 222-241$.

Salomon, G., \& Perkins, D. (1996). Learning in wonderland. In Kerr, S. T. (Eds.), Technology and the future of schooling (pp.111-129). Chicago, IL: National Society for the Studies in Education.

Sawyer, R.K. (2003). The mechanisms of emergence. Philosophy of the Social Sciences, 34(2), $260-282$.

Sawyer, R.K. (2004). Creative teaching: Collaborative discussion as disciplined improvisation. Educational Researcher, 33(2), 12-20.

Scardamalia, M. (2002). Collective cognitive responsibility for the advancement of knowledge. In B. Smith (Eds.), Liberal education in a knowledge society (pp.67-98). Chicago, IL: Open Court.

Scardamalia, M. (2004). CSILE/Knowledge Forum ${ }^{\circledR}$. In A. Kovalchick, \& K. Dawson (Eds.), Education and technology: An encyclopedia (pp. 183-192). Santa Barbara, CA: ABC-CLIO, Inc.

Scardamalia, M., \& Bereiter, C. (1991). Higher levels of agency for children in knowledge building: A challenge for the design of new knowledge media. Journal of the Learning Sciences, 1 (1),37-68. 
Scardamalia, M., \& Bereiter, C. (2006). Knowledge building: Theory, pedagogy, and technology. In K. Sawyer (Eds.), Cambridge handbook of the learning sciences (pp. 97118). New York, NY: Cambridge University Press.

Schwartz, D., Lin, X., Brophy, S., \& Bransford, J. (1999). Toward the development of flexibly adaptive instructional designs. In C. Reigeluth (Ed.), Instructional design theories and models Vol. II (pp. 183-213). Mahwah, NJ: Lawrence Erlbaum Associates.

Stevenson, H. W., \& Stigler, J. (1992). The learning gap. New York, NY: Summit Books.

Tu, C.H. \& Twu, H. L. (2002). Educational technology in Taiwan. Education Media International, $\underline{39}(2), 153-164$.

Tweed, R.G., \& Lehman, D.R. (2002). Learning considered within a cultural context: Confucian and Socratic Approaches. American Psychologist, 57(2), 89-99.

UNESCO (2005). Towards knowledge societies. Paris: United Nations Educational, Scientific, and Cultural Organization.

van Aalst, J., \& Chan, C.K.K. (2007). Student-directed assessment of knowledge building using electronic portfolios. Journal of the Learning Sciences, $\underline{16}(2), 175-220$.

van Joolingen, W.R., \& de Jong, T. (2007). Issues in computer supported inquiry learning in science. Journal of Computer Assisted Learning, 23 (2), 111-119.

Wertsch, J.V. (1998). Mind as action. New York: Oxford University Press.

Windschitl, M., \& Sahl, K. (2002). Tracing teachers' use of technology in a laptop computer school. American Educational Research Journal, 39(1), 165-205.

Zhang, J. (2002). Incorporating ICT into K-12 schools. TechTrends, $\underline{46}(4), 51-57$.

Zhang, J. (2007). A cultural look at information and communication technologies in Eastern education. Educational Technology Research and Development, 55(3), 301-314. 
Zhang, J., \& Scardamalia, M. (2007). Sustaining principle-based knowledge building innovation at an elementary school. Paper presented at the Annual Meeting of American Educational Research Association, Chicago, IL.

Zhang, J., Hong, H.-Y., Teo, C., Scardamalia, M., \& Morley, E. (2008). “Constantly going deeper:" Knowledge building innovation in an elementary professional community. Paper presented at the Annual Meeting of American Educational Research Association, New York.

Zhang, J., Scardamalia, M., Lamon, M., Messina, R., \& Reeve, R. (2007). Socio-cognitive dynamics of knowledge building in 9- and 10-year-olds. Educational Technology Research and Development, $\underline{55}, 117-145$.

Zhang, J., Scardamalia, M., Reeve, R., \& Messina, R. (2009). Designs for collective cognitive responsibility in knowledge building communities. Journal of the Learning Sciences, 18, 7-44.

Zhang, J., Wu, G., \& Li, F. (2003). The current status of online learning under implementation: A survey of distance learners. Open Education Research, 9(4), 5-12 (in Chinese).

Zhu, Z., Gu, X., \& Wang, Q. (2003). A panorama of online education in China. Educational Technology, $\underline{43}(3), 23-27$.

Ziguras, C. (2001). Educational technology in transnational higher education in South East Asia. Educational Technology \& Society, $\underline{4}(4), 8-18$. 


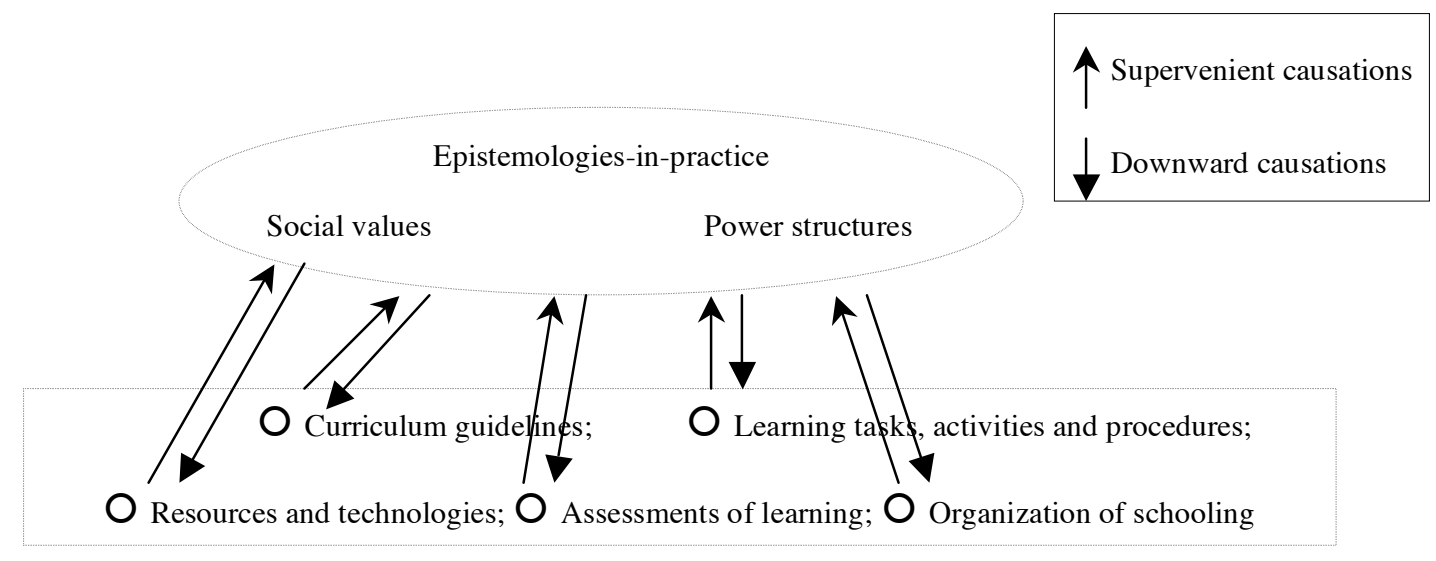

Figure 1. Interactions between macro-level properties and micro-level components in a learning culture. 